\title{
U ZARANIA ŁACIŃSKIEGO POJĘCIA OSOBY (PERSONA) Przyczynek do teologicznego myślenia o osobie
}

Przypomnienie źródłowej bazy pojęcia persona ma kluczowe znaczenie w refleksji teologicznej nad osobą. Pozwala nam bowiem dostrzec już w punkcie wyjścia, że nie można jej sprowadzić do filozoficznych terminów individuum czy też rationalis naturae individua substantia (zindywidualizowana, jednostkowa natura rozumna), jak to zostało sformułowane w klasycznej definicji Boecjusza ${ }^{1}$. Jak wiadomo, pierwsze znaczenie persona wybiega poza czysto metafizyczne pojęcie osoby. Podobnie też jej zakorzenienia nie da się zredukować do teologicznego terminu. Zanim Tertulian wprowadzi go na stałe do łacińskiego słownika teologicznego, wyraz persona występuje najpierw zarówno w świecie teatru, w dziedzinie gramatyki, jak i w języku prawnym. $\mathrm{Na}$ początku pokrótce naświetlimy to zagadnienie znaczenia persona w klasycznym języku łacińskim. Następnie, na gruncie semantycznej analizy słowa persona, będzie można uwydatnić jego chrześcijańską specyfikę w języku teologicznym Tertuliana, który odegrał istotną rolę w procesie tworzenia się oryginalnego słownictwa chrześcijaństwa łacińskiego ${ }^{2}$.

Dla znawców problematyki nie jest bynajmniej tajemnicą, że podjęta tu tematyka była już wielokrotnie omawiana. Stanowi ona wciąż przedmiot prac i artykułów naukowych. Dla przykładu wymienię trzy francuskojęzyczne pozycje bibliograficzne, które zainspirowały bezpośrednio moje własne analizy i przemyślenia z teologicznego punktu widzenia: Joseph Moingt, Théologie trinitaire de Tertullien (Teologia trynitarna Tertuliana), t. 2: Substantialité et individualité (Substancjalność i jednostkowość), Théologie 69, Paris 1966; La personne et le christianisme ancien, éd. Bernard Meunier, Patrimoines christianisme, Paris 2006; Emmanuel Housset, La vocation de la personne. L'histoire du concept de personne de sa naissance augustinienne à sa redécouverte phénoménologique, Epiméthée, Paris 2007.

\footnotetext{
* Ks. dr hab. Krzysztof Witko - teolog, patrolog; kapłan diecezji Nanterre pod Paryżem, proboszcz parafii w Issy-les-Moulineaux; e-mail: witko.krzysztof@gmail.com.

${ }^{1}$ Por. K. Wojtyła, Osoba i czyn, Kraków 1985², 95.

${ }^{2}$ Por. Histoire du christiansime, t. 1: Le nouveau peuple (des origines à 250), éd. L. Pietri et allii, Paris 2000, 882-892.
} 
1. Znaczenie persona w lacinie klasycznej. Trzeba od razu podkreślić, że w odróżnieniu od greckiego $\pi \rho o ́ \sigma \omega \pi$ ov (etymologicznie: „to, co jest przed oczyma”, „twarz”, „oblicze”, „czołówka”, „fasada”), etymologia łacińskiego wyrazu persona nie jest określona jednoznacznie. Niektórzy znawcy problematyki wysuwają hipotezę, że samo słowo wywodzi się od etruskiego słowa Phersu (lub Phersuna), które można tłumaczyć słowami - maska lub zasłonięty maską (zamaskowany) ${ }^{3}$. Opierając się jednak na nowszych opracowaniach, mamy pełne prawo uważać, że wyraz persona został bezpośrednio zapożyczony z języka greckiego i wywodzi się od słowa $\pi \rho o ́ \sigma \omega \pi$ ov, które to począwszy od wieku IV prz. Chr. było używane w języku greckim na określenie nie tylko maski, którą aktor zakładał na scenie, lecz również najczęściej samej postaci teatralnej. Nie należy też zapominać, że w tym samym okresie gramatycy greccy używali wyrazu $\pi \rho o ́ \sigma \omega \pi$ ov na określenie osób gramatycznych ${ }^{4}$.

Jeśli chodzi o pierwsze znaczenia słowa persona w języku łacińskim w okresie starożytnym, można zauważyć, że pojawia się ono najpierw w obszarze pozafilozoficznym i pozateologicznym. Daje się łatwo zaobserwować w trzech dziedzinach. Po pierwsze, odnosi się do teatru i oznacza najpierw rolę lub postać teatralną. Takie znaczenie persona znajdujemy u Plauta (ok. 250-184) w komedii pt. Pers 5 i u Terencjusza (ok. 195-159) w komedii zatytułowanej Eunuch ${ }^{6}$. Od wieku II prz. Chr. przyjmuje również znaczenie „maski”, np. u Akcjusza (ok. 170-85)7. Po drugie, od I w. prz. Chr. znaczenie persona wchodzi w dziedzinę gramatyki i oznacza formy osobowe czasownika, o czym zaświadcza pisarz i uczony rzymski Marcus Terentius Varro, zwany Warronem z Reate ${ }^{8}$. W końcu wyraz persona nabiera znaczenia prawnego i określa jednostkę ludzka, osobę fizyczną, którą stanowią ludzie wolni i niewolnicy, mężczyźni i kobiety. Takie rozumienie persona występuje wyraźnie w tekstach jurysty rzymskiego Gajusa (koniec II w. po Chr.). W jego podręczniku do nauki prawa Instytucje, prawo dotyczy zarówno osób (personas),

${ }^{3}$ Por. F. Skutsch, Persona, w: Archiv für lateinische Lexikographie und Grammatik, t. 15, hrsg. E. von Wölfflin, Leipzig 1908, 145-146; M. Nédoncelle, Prosopon et persona dans l'Antiquité classique, RSR 82 (1948) 277-299. Odnośnie do znaczenia słów, zob. J.-R. Jannot, Phersou Phersuna, Persona. A propos du masque étrusque, w: Spectacles sportifs dans le monde étrusco-italique. Actes de la table ronde de Rome (3-4 mai 1991), Collection de l'Ecole française de Rome 172, Rome 1983, 292 (cały tekst: s. 281-320).

${ }^{4}$ Por. F. Létoublon, La personne et ses masques: remarques sur le développement de la notion de personne et sur son étymologie dans l'histoire de la langue grecque, „Faits de langues” 3 (1994) 8-10; Housset, La vocation de la personne, s. 39.

${ }^{5}$ Por. Titus Maccius Plautus, Persa 783.

${ }^{6}$ Por. Publius Terentius Afer, Eunuchus 26-35.

${ }^{7}$ Wzmianka zapisana u uczonego rzymskiego Warrona z Reate (ok. 116-27) w dziele De lingua latina 7, 64. Por. B. Meunier, „Persona” en latin classique, w: La personne et le christianisme ancien, éd. B. Meunier, Patrimoines - christianisme, Paris 2006, 23.

${ }^{8}$ Por. De lingua latina 8,$20 ; 9,32 ; 9,95 ; 9,100-102$. 
rzeczy (res), jak i powództw (actiones) ${ }^{9}$. Te trzy podstawowe znaczenia słowa persona znalazły szeroko swe zastosowanie zarówno w tekstach Cycerona (106-43), jak i Seneki Młodszego (ok. 4 prz. Chr. - 65 po Chr.), jak wykazał to francuski znawca starożytności - B. Meunier ${ }^{10}$. Przedstawię teraz pokrótce wyniki jego badań.

W I w. prz. Chr., Cyceron jest świadkiem zastosowania słowa persona nie tylko w klasycznym znaczeniu maski lub roli teatralnej, zachowanym do końca epoki starożytnej, lecz także w praktyce życia społecznego. Oznacza to, że w języku rzymskiego polityka i myśliciela wyraz persona wskazuje na człowieka rozumianego jako byt społeczny. Wiąże się z opisem jego statusu społecznego i pozycji zawodowej ${ }^{11}$.

W dziele De finibus bonorum et malorum Cyceron używa słowa persona w znaczeniu ,figura”, „model” lub „postać”, zakorzenionemu w teatralnym rozumieniu roli czy też bohatera literackiego ${ }^{12}$. W każdym razie persona $\mathrm{w}$ jego pismach i mowach nie odnosi się do konkretnej i niepowtarzalnej osoby, ale do profilu społeczno-zawodowego ludzi. W podręczniku do retoryki De inventione posługuje się w opisie osób takimi kategoriami jak: imię (nomen), charakter (natura), sposób bycia (victus), status społeczny (fortuna), sprawność (habitus), afekt (adfectio), upodobania (studia), zamiary i dążenia (consilia), zachowania (facta), zdarzenia (casus), sposób wypowiedzi (orationes) ${ }^{13}$.

Zdaniem B. Meuniera, Cyceron jest świadkiem pojęcia persona wskazującego na wymiar społeczno-moralny człowieka ${ }^{14}$. W łacinie klasycznej nie zawiera on wszakże podstawowego dla chrześcijaństwa pojęcia konkretnego człowieka, jego wyjątkowości (jedyności) i niepowtarzalności ${ }^{15}$. Persona w klasycznym języku łacińskim sprowadza się do fizycznych, społecznych i zawodowych cech człowieka. W zasadzie można przyjąć, że wskazuje na ogólne i powszechne ludzkie zachowania i działania w społeczeństwie ${ }^{16}$.

Aby jeszcze wyraźniej podkreślić ten zewnętrzny i pragmatyczny charakter wyrazu persona w myśli Cycerona, rzućmy okiem na krótki fragment jego dzieła De officiis - napisanego pod koniec życia, jesienią 44 r. prz. Chr. - w którym występuje słowo persona. Tekst podejmuje sprawę stosowności

\footnotetext{
${ }^{9}$ Por. Meunier, „Persona” en latin classique, s. 23-24; Housset, La vocation de la personne, s. 39-40; Létoublon, La personne et ses masques, s. 10.

${ }^{10}$ Por. Meunier, ,, Persona” en latin classique, s. 23-28.

${ }^{11}$ Por. tamże, s. 24.

${ }^{12}$ Por. np. Cicero, De finibus bonorum et malorum III 75, gdzie występuje wyrażenie persona sapientis wskazujące na postać, figurę czy też typ mędrca.

${ }^{13}$ Por. tenże, De inventione I 34, ed. T.E. Page - E. Caps - W.H.D. Rouse, LCL 386, Cambridge (Mass.) - London 1960, 70: „Ac personis has res adtributas putamus: nomen, naturam, victum, fortunam, habitum, affectionem, studia, consilia, facta, casus, orationes".

${ }^{14}$ Por. Meunier, ,Persona” en latin classique, s. 25.

${ }^{15}$ Por. Wojtyła, Osoba i czyn, s. 95-96.

${ }^{16}$ Por. Meunier, ,Persona” en latin classique, s. 25.
} 
w zachowaniu (decorum), która oznacza zgodność naszego działania z tym, czym jesteśmy. Natura ludzka przeniesiona niejako ze świata zewnętrznego do świata wewnętrznego wszystkich ludzi stanowi tu klucz do wyróżnienia dwóch różnych „,form” lub ,jakości” owej specyficznej rzeczywistości ludzkiej, jaka odpowiada pojęciu persona. Pisze Cyceron:

„Trzeba jeszcze zrozumieć, że natura poniekąd przyodziała nas w dwie postacie (duabus [...] personis): jedna jest nam wszystkim wspólna, z tej racji, że wszyscy mamy udział w rozumie i tej godności, która wynosi nas ponad zwierzęta. Z niej wypływają pełnia piękna moralnego (honestum) i pełnia stosowności w zachowaniu (decorum); i ona to stanowi miarę do poznania obowiązków. Co do drugiej, została ona udzielona każdemu z osobna"17.

W następnych zdaniach tekstu Cyceron wyjaśnia, że owa druga „postać” (persona) odnosi się nie tylko do ciał (cechy fizyczne), lecz także do dusz, tzn. do temperamentu i cech moralnych (dissimilitudines naturae morumque) ${ }^{18}$. Biorąc pod uwagę istnienie tych dwóch ,postaci” (personae), stosowność w zachowaniu polegać będzie na syntezie działania, które nie będzie sprzeczne $\mathrm{z}$ naturą właściwą wszystkim ludziom (contra universam naturam) ${ }^{19}$ i działania, które jednocześnie będzie w zgodzie $\mathrm{z}$ własną naturą (propriam naturam $)^{20}$. Jak widać $\mathrm{z}$ powyższego dwie różne personae wzmiankowane w De officiis I 107 odpowiadają tu znaczeniu dwóch różnych naturae. Wydaje się więc, że w dyskursie Cycerona rzeczownik liczby mnogiej personae utożsamia się z rzeczownikiem naturae ${ }^{21}$.

W dalszej części księgi I De officiis na nowo pojawia się wyraz perso$n a^{22}$. Tu również posiada on dwa różne znaczenia. Niekiedy persona pozostaje w ścisłym związku z treścią słowa „osobowość” czy też „osobistość” społeczna, na którą spogląda się od strony takich kategorii społecznych jak: władza, uznanie, bogactwo, albo ich antonimy. Innym razem persona wskazuje na „rolę" społeczna, jaką wybieramy sobie czy też której oddajemy się (np. filozofii, prawu, etc.). Język łaciński dysponuje tutaj określeniem personam gerere: „odgrywać rolę, pełnić funkcję"23. Ale tak rozumiana persona nie oznacza bynajmniej w pełni świadomego podmiotu istnienia i działania, i nie

${ }^{17}$ Cicero, De officiis I 107, ed. T.E. Page - W.H.D. Rouse, LCL 30, London - New York 1913, 108: ,Intellegendum etiam est duabus quasi nos a natura indutos esse personis; quarum una communis est ex eo, quod omnes participes sumus rationis praestantiaeque eius, qua antecellimus bestiis, a qua omne honestum decorumque trahitur et ex qua ratio inveniendi officii exquiritur, altera autem quae proprie singulis est tributa", thum. własne.

${ }^{18}$ Tamże I 109.

${ }^{19}$ Tamże I 110.

${ }^{20}$ Tamże.

${ }^{21}$ Por. Meunier, ,,Persona” en latin classique, s. 25.

${ }^{22}$ Por. Cicero, De officiis I 115.

${ }^{23}$ Por. Meunier, ,Persona” en latin classique, s. 25-26. 
można utożsamić jej z pojęciem „osoba” we współczesnym znaczeniu. Klasyczny język łaciński dokonuje niejako ,reifikacji” osoby, sprowadzając ją do roli, jaką ma do odegrania czy też wypełnienia w społeczeństwie.

Inny myśliciel rzymski na przełomie ery starożytnej i nowożytnej, Seneka Młodszy, używa wyrazu persona w jego klasycznym znaczeniu ${ }^{24}$. W swych dialogach filozoficznych De beneficiis słowo persona, podobnie jak Cyceron, odnosi do roli społecznej i statusu prawnego człowieka ${ }^{25}$. Zgodnie ze swą etymologia, persona może być u niego rozumiana jako,,ważna osobistość (tanta persona)"26, a nawet też w znaczeniu pejoratywnym: wskazuje na człowieka, który przybiera „maskę” zasłaniającą rzeczywistość, w odróżnieniu od facies ukazująca , prawdziwe oblicze"27. W końcu w dialogach De consolatione ad Helviam matrem (XVII), wyrażenie in mea tamen persona oznacza, jeśli chodzi o mnie", a zwrot in persona patris, użyty w De consolatione ad Marciam (I 2), odpowiada polskiemu - „co się tyczy twojego ojca”. Słowem, Seneka nie wykracza poza klasyczne użycie słowa persona i nie zna jego innego znaczenia niż to, które określa człowieka od strony roli społecznej, która wyznacza mu określoną pozycję i prawny status w otaczającym go świecie.

Reasumując, trudno się jednak zgodzić z konkluzją B. Meuniera, według którego w starożytności łacińskiej nie ma miejsca na filozoficzny status osoby $^{28}$. E. Housset słusznie zwrócił uwagę na fakt, że zapewne zainspirowane filozofią stoicką i obecne już w dziełach Cycerona znaczenie moralno-prawne wyrazu persona, a później w tekstach jurysty rzymskiego Gajusza, zapowiada i przygotowuje narodziny pojęcia osoby w jej filozoficznym ujęciu, rozumianej jako bytu świadomego swego uprzywilejowanego miejsca w świecie, odpowiedzialnego za swój los i zdolnego do wolnych aktów decyzyjnych ${ }^{29}$. Tak więc już w pogańskiej kulturze łacińskiej dokonuje się wyraźnie przejście pojęcia persona z poziomu języka teatralnego na poziom ludzkiej egzystencji w otaczającym ją świecie. Nie pozostawszy tylko na poziomie konkretu (maska), wzniosło się na poziom abstraktu (postać, rola społeczna); w ten sposób w oparciu o zewnętrzny świat zmysłów niesie z sobą bardziej uniwersalny poziom idei - poziom wyjątkowości ludzkiej kondycji i praw dla wszystkich ludzi. Ale percepcja wyrazu persona, obecna w kulturze łacińskiej, osiagnie pełniejsze rozumienie $\mathrm{w}$ zetknięciu się $\mathrm{z}$ chrześcijańskim Objawieniem. Tertulian jest właśnie świadkiem kluczowej roli pojęcia persona w teologii Kościoła łacińskiego na początku III wieku.

${ }^{24}$ Por. tamże, s. 26-27.

${ }^{25}$ Por. Lucius Annaeus Seneca (Minor), De beneficiis II 16, 2; III 28, 1; IV 28, 5, Zob. Meunier, „Persona" en latin classique, s. 26, noty 1-2.

${ }^{26}$ Por. Lucius Annaeus Seneca (Minor), De ira III 40, 2.

${ }^{27}$ Por. tenże, De beneficiis II 13, 2. Zob. Meunier, „Persona” en latin classique, s. 27.

${ }^{28}$ Por. Meunier, ,Persona” en latin classique, s. 27-28.

${ }^{29}$ Por. Housset, La vocation de la personne, s. 40-41. 
2. Termin persona u Tertuliana. Tertulian († po 220) odegrał ogromną rolę w procesie kształtowania się języka teologicznego na Zachodzie. Uchodzi za ojca teologii łacińskiej. Do jej terminologii wprowadził około 900 nowych słów bądź ich nowych znaczeń (np. sakrament, substancja i osoba) ${ }^{30}$. W przeciwieństwie do łaciny klasycznej, jego teologiczne rozumienie terminu persona nie odnosi się już do terminologii teatralnej, lecz nabiera nowego znaczenia wskazującego na trzy odrębne Osoby w Bogu. Umieszczając termin persona po stronie Boga i w Bogu, nie tylko dokonuje przeniesienia go ze sfery człowieka do sfery Boga, lecz nade wszystko umożliwia wyłonienie się doktryny trynitarnej w teologii łacińskiej. Jest zapewne tym, który jako pierwszy wprowadził na stałe rozróżnienie pomiędzy „substancją” a „osobą”. Jakkolwiek słowo „substancja” nie ma jeszcze u niego treści nicejskiego wyznania wiary (325) i - w reakcji na błąd modalizmu, wedle którego Syn (i Duch Święty) to tylko określony sposób ukazania się jedynego Boga-Ojca czy też przejaw tego samego bytu - oznacza, że Syn istnieje realnie mocą niepodzielnej, ale jednocześnie udzielnej „substancji”, którą otrzymuje od Ojca, to wyraźnie naprowadza teologię łacińską na ścieżkę prowadzącą niezawodnie do odsłonięcia jedności i niepodzielności Boskiej substancji ${ }^{31}$. Tymczasem wprowadzenie wyrazu persona (osoba) do refleksji nad Trójcą objawioną w ekonomii zbawienia wydobywa na jaw aspekt „,wielości” i „odrębności” poszczególnych Osób w Trójcy. W ten sposób w sformułowanym przez niego wyrażeniu ,jedna substancja w trzech ściśle powiązanych ze sobą [osobach]" 32 widać właściwe źródło klasycznej formuły trynitarnej ,jedna natura w trzech Osobach" 33 . By lepiej zrozumieć rolę Tertuliana w procesie kształtowania się teologicznego rozumienia terminu persona ${ }^{34}$, pokrótce omówię jego znaczenie w refleksji

${ }^{30}$ Por. J. Wolinski, De l'économie à la ,théologie” (III siècle), w: B. Sesboüé - J. Wolinski, Histoire des Dogmes, t. 1: Le Dieu du Salut, dir. B. Sesboüé, Paris 1994, 202 = J. Wolinski, Sans cesse engendrés dans le Christ. Treize études patristiques, Religie świata - świat religii 12, Lublin 2013, 252.

${ }^{31}$ Por. tamże.

${ }^{32}$ Tertullianus, Adversus Praxean 12, 7, ed. A. Kroymann - E. Evans, CCL 2, Turnhout 1954, 1173: „unam substantiam in tribus cohaerentibus”, thum. Własne.

${ }^{33}$ Por. Wolinski, De l'économie à la ,théologie" (III siècle), s. 202-203 = Wolinski, Sans cesse engendrés dans le Christ, s. 252-253.

${ }^{34} \mathrm{~W}$ ramach niniejszych rozważań nie zamierzam podejmować problematyki tzw. egzegezy prosopograficznej czy też prosopologicznej, obecnej w pismach chrześcijańskich autorów (np. Justyn, Tertulian, Orygenes, Atanazy Wielki, Euzebiusz z Cezarei, Dydym Ślepy, Diodor z Tarsu, Teodor z Mopsuestii, Teodoret z Cyru, Hilary z Poitiers i Augustyn z Hippony), w której wyraz „osoba” ( $\pi \rho o ́ \sigma \omega \pi \mathrm{ov}$, persona) odgrywał ogromną rolę. Niewątpliwie stanowi ona niejako „pole startowe” dla ukształtowania się teologicznego pojęcia „osoby” w dyskursie trynitarno-chrystologicznym starożytnego Kościoła od początku III do V w. Warto podkreślić, że była ona już znana i szeroko stosowana w starożytnej nauce o literaturze zarówno przez stoików, jak i Filona z Aleksandrii († 40). Por. np. C. Andresen, Zur Entstehung und Geschichte des trinitarischen Personenbegriffs, ZNW 52 (1961) 1-39; M.-J. Rondeau, Les Commentaires patristiques du Psautier (III ${ }^{e}-V^{e}$ siècles), 
tego wybitnego Afrykańczyka w odniesieniu zarówno do tajemnicy Trójcy Świętej, jak i do osoby Chrystusa.

a) Persona w dyskursie trynitarnym. Użycie wyrazu persona w pismach Tertuliana stanowi szczególnie ważny moment w odsłonięciu tajemnicy trynitarnej Boga Ojca, Syna i Ducha. Leży niejako u źródeł łacińskiej teologii trynitarnej. Wiadomo też, że w dziele Adversus Praxean (Przeciw Prakseaszowi) słowo to pozwala mu na odparcie modalistycznego błędu Prakseasza ${ }^{35}$, sprowadzającego nazwy Ojca, Syna i Ducha Świętego jedynie do kolejnych imion samowyrażającego się jedynego Boga w odniesieniu do Jego trzech ekonomicznych (zewnętrznych) sposobów działania: w dziele stworzenia Bóg objawił się jako Ojciec, w dziele wcielenia jako Syn, a w dziele uświęcania jako Duch Święty. Pisze Tertulian w swym kluczowym tekście dążącym do wyrażenia tajemnicy Boga, w którym doskonała jedność splata się z pojęciem realnej wielości („trzej: tres”) będącej integralną częścią tej jedności:

„A przecież Jeden (unus) jest także wszystkim (omnia), skoro wszystko (omnia) pochodzi z jednego (ex uno) z racji jedności substancji; lecz mimo to jest zachowana tajemnica ekonomii, która wprowadza jedność do Trójcy (oikonomiae sacramentum quae unitatem in trinitatem disponit): Ojciec, Syn i Duch są trzema (tres), ale trzema nie co do stanu (statu), ale co do stopnia (gradu), nie co do substancji (substantia), a co do formy (forma), nie co do mocy (potestate), lecz co do postaci (specie). Są zatem jednej substancji (unius substantiae), jednego stanu i jednej mocy, ponieważ jest jeden Bóg, od którego są (ex quo) owe stopnie, formy i postaci, i które to określamy imionami Ojca, Syna i Ducha Świętego (in nomine patris et filii et spiritus sancti deputantur)"36.

Niniejszy przyczynek nie pretenduje rzecz jasna do pogłębionego studium nad teologicznym dziełem Tertuliana. Nie ma też potrzeby szczegółowej analizy terminów użytych w powyżej cytowanym fragmencie jego dzieła Przeciw Prakseaszowi. Pisano już o tym wiele razy ${ }^{37}$. Przytoczony tu tekst ma dla mnie znaczenie z uwagi na umiejscowienie kontekstu użycia pojęcia „osoba”

t. 2: Exégèse prosopologique et théologie, OCA 220, Rome 1985; M. Slusser, The exegetical Roots of Trinitarian Theology, ThS 49 (1988) 461-476; J. Ratzinger, Znaczenie osoby w teologii, „Personalizm" 8 (2005) 35-48.

${ }^{35}$ Por. R. Doumas, „Persona” chez Tertullien (sur la base de deux textes de l'«Adversus Praxean»), w: La personne et le christianisme ancien, s. 29-44.

${ }^{36}$ Tertullianus, Adversus Praxean 2, 4, CCL 2, 1161: „quasi non sic quoque unus sit omnia dum ex uno omnia, per substantiae scilicet unitatem, et nihilo minus custodiatur oikonomiae sacramentum quae unitatem in trinitatem disponit tres dirigens patrem et filium et spiritum, tres autem non statu sed gradu, nec substantia sed forma, nec potestate sed specie, unius autem substantiae et unius status et unius potestatis, quia unus deus ex quo et gradus isti et formae et species in nomine patris et filii et spiritus sancti deputantur", tłum. własne.

${ }^{37}$ Por. Moingt, Théologie trinitaire de Tertullien, t. 2, passim. Zob. Wolinski, De l'économie à la „théologie" (III siècle), s. 192-193 = Wolinski, Sans cesse engendrés dans le Christ, s. 242-243. 
przez Afrykańczyka. Odsłania on mianowicie chrześcijańską świadomość oryginalności spojrzenia na tajemnicę Boga jedynego, objawionego w Jezusie Chrystusie, odwiecznym Synu Boga Ojca. Dla Tertuliana starotestamentalny monoteizm (por. Pwt 6,4 ) był na wskroś naturalny $i$ wiara $w$ jedynego Boga nie stanowiła żadnego problemu. Jednakże wiara $\mathrm{w}$ objawionego Boga $\mathrm{W}$ Jezusie Chrystusie wymagała zmiany w sposobie podejścia do tajemnicy Boga. A zatem zgodnie z Objawieniem rzeczywistość Boga jedynego zasadza się na swoistości, odrębności i niepowtarzalności poszczególnych „Osób” Boskich: Ojca, Syna i Ducha. Trzeba dodać od razu, że refleksja Tertuliana prowadzi do zachowania obydwu stron monoteizmu trynitarnego. Wprowadzenie liczby „trzej” (tres) do sfery Jedynego Boga (unus) nie unicestwia bynajmniej Jego doskonałej jedności. Jest oczywiste dla Tertuliana, że istnieje tylko jeden Bóg, albowiem od Jedynego są wszyscy Trzej (dum ex uno omnia). Niemniej przeto „Jedyny” nie unicestwia odrębności i swoistych cech wyróżniających poszczególne „osoby” Boskie w łonie tej samej substancji (natury) ${ }^{38}$.

W świetle powyższego odsłania się teologiczny sens wyrazu persona, użytego dwa razy w poniżej cytowanym krótkim fragmencie dzieła Przeciw Prakseaszowi:

„Zwrócony [do Słowa] i uradowany uradowanym Swoją Osobą (in persona illius) rzecze: «Tyś jest Synem moim, jam cię dziś zrodził» (Ps 2, 7) [...]. Podobnie i Syn, we własnej osobie (ex sua persona), pod imieniem Mądrości, świadczy o Ojcu, mówiąc: «Pan ustanowił mnie początkiem swych dróg dla dzieł swoich, przed wszystkimi wzgórzami mnie zrodził» (Prz 8, 22. 25)"39.

Używając wyrazu „osoba” (persona), Tertulian wskazuje na dwa różne podmioty gramatyczne (Ojciec i Syn) w dwóch przytoczonych zdaniach skrypturystycznych (Ps 2,7 i Prz 8, 22. 25). Ten sposób interpretacji Pisma Świętego - opartej na metodzie prosopologicznej (odpowiadającej na pytanie: kto mówi w tekście?) - pozwala mu nadać osobie gramatycznej (podmiotowi zdania) określoną rzeczywistość, a w dalszej konsekwencji - realną postać. Tego rodzaju zabieg interpretacyjny sprawia, że rozumienie osoby nie sprowadza się do ,językowej gry" czy też literackiej kreacji określonej roli usiłującej wypowiedzieć jakąś chwilową, „tymczasową” świadomość siebie. Osoba u Tertuliana jest odzwierciedleniem czynnej i realnej odrębności „Boskich hipostaz", ich niepowtarzalności i osobliwego charakteru. Tym sposobem osoba posiada w sobie nie tylko charakter „odgrywanej roli” przez Boga działającego w świecie (na sposób ,grania roli” w dramacie), ale jak najwierniej uwidacznia specyficzną realność i tożsamość wspólnoty osób Boskich (realna Boska

${ }^{38}$ Por. Wolinski, De l'économie à la ,théologie" (III siècle), s. 202-203 = Wolinski, Sans cesse engendrés dans le Christ, s. 252-253.

${ }^{39}$ Tertullianus, Adversus Praxean 7, 2-3, CCL 2, 1165: „Ad quem deinceps gaudens proinde gaudentem in persona illius: «Filius meus es tu, ego hodie generaui te» [...]. Sic et filius ex sua persona profitetur Patrem in nomine sophiae: Dominus condidit me initium viarum in opera sua; ante omnes autem colles generauit me»”, thum. własne. 
jedność splata się z realną odmiennością poszczególnych Osób Boskich). Tą ścieżką wytyczoną przez Tertuliana pójdzie dalej św. Augustyn, pogłębiając refleksję trynitarną na Zachodzie w oparciu o pojęcie osoby w Bogu, rozumianej jako doskonała relacja ${ }^{40}$ (czysta więź i interakcja).

Opierając się na powyższym rozumieniu refleksji trynitarnej Tertuliana, mamy pełne prawo uważać, że „osoba” Boska posiada u niego charakter na wskroś dialogiczny. Niewątpliwie wprowadzenie dialogu do refleksji nad tajemnicą Boga objawionego na kartach Pisma Świętego pozwala odkryć Boga Jedynego w Trójcy Osób. Takie podejście zakłada, że Bóg jest nie tyle „Absolutem bytu", ile wspólnotą Osób w dialogu, przepełnionych wzajemną miłością i wzajemnie udzielającym się darem. Można powiedzieć, że w sporze z modalizmem Tertulianowe pojęcie osoby odsyła nas do prawdy o Bogu, który w swej nieskończonej jedności zachowuje wewnętrzne zróżnicowanie i dialogiczną wspólnotę we wnętrzu życia Trójcy Świętej.

b) Persona w dyskursie chrystologicznym. Jak już wspomniałem uprzednio, u Tertuliana teologiczne rozumienie wyrazu „osoba” wiąże się również z wprowadzeniem go do refleksji o Wcieleniu Słowa Bożego. Jakkolwiek w jego nauczaniu persona nie ma jeszcze treści metafizycznego pojęcia osoby $^{41}$, jest ona jednak czymś więcej niż tylko podmiotem gramatycznym i czymś innym niż świadomością samego siebie, dzięki której umysł jest świadomy swego konkretnego bytowania jako jeden $\mathrm{z}$ wielu samodzielnych podmiotów bytowania i działania. Osoba łączy się u niego z ideą, według której człowieczeństwo nie wyrzeka się siebie i nie ginie bezpowrotnie w spotkaniu $\mathrm{z}$ nieskończonym Bogiem. W Jezusie Chrystusie jest w pełni podtrzymana odrębność zarówno Boskiej, jak i ludzkiej rzeczywistości ${ }^{42}$. Czytamy w dziele Przeciw Prakseaszowi:

„Widzimy [w Chrystusie] dwa stany (statum) - które nie są zmieszane, lecz złączone (non confusum sed coniunctum) w jednej osobie - Boga i człowieka Jezusa (in una persona deum et hominem Iesum)" ${ }^{\prime 3}$.

W tym zdaniu Tertuliana nie możemy szukać pełnej treści chalcedońskiej koncepcji unii hipostatycznej z 451 r., orzekającej o Jezusie Chrystusie jako jedynym podmiocie (osobie) po Wcieleniu, łączącym w sobie doskonałe bóstwo i doskonałe człowieczeństwo, „bez zmieszania, bez zmiany, bez rozdzielania i rozłączania" natury boskiej i natury ludzkiej. Jednakże jego kapitalne wyrażenie „dwa stany (Bóg i człowiek) w jednej osobie” pozwala dostrzec w nim

\footnotetext{
${ }^{40}$ Por. Augustinus, De Trinitate III 4, PL 42, 873 ; tamże V 1, PL 42, 911.

${ }^{41}$ Por. Wolinski, De l'économie à la "théologie" (III siècle), s. 201 = Wolinski, Sans cesse engendrés dans le Christ, s. 251.

${ }^{42}$ Por. Tertullianus, Adversus Praxean 27, 11-13.

${ }^{43}$ Tamże 27, 11, CCL 2, 1199: „Videmus duplicem statum, non confusum sed coniunctum, in una persona deum et hominem Iesum", thum własne
} 
i określić korzenie chrystologicznej formuły wiary Soboru Chalcedońskiego ${ }^{44}$. Więcej, pozwala również ustalić, iż w Jezusie pomiędzy Bogiem i człowiekiem zachodzi swoista spójność (coniunctum). Spójność ta daje się najpełniej i najlepiej wyrazić poprzez słowo „osoba”. Osoba Jezusa jest podstawą i szczytowym punktem istotowej spójności pomiędzy Bogiem i człowiekiem. Właśnie w chrystologicznym pojęciu osoby tkwi pełna i definitywna gwarancja utrzymania w mocy misterium spełnionego spotkania i wzajemnego przenikania bóstwa i człowieczeństwa, bez najmniejszego ryzyka ich wzajemnego umniejszenia i pomieszania (non confusum).

Reasumując, należy zauważyć, że wyraz persona w refleksji Tertuliana pozwala adekwatnie ująć i wyrazić dwa aspekty Objawienia Boga w Jezusie Chrystusie. Patrząc od strony dyskursu trynitarnego, w pojęciu persona znajduje swój pełny wyraz doskonała odrębność (cechy swoiste) Osób Boskich. Tymczasem podstawowe znaczenie słowa persona $\mathrm{w}$ odniesieniu do Chrystusa (dyskurs chrystologiczny) wskazuje na Bożą moc jednania (spójność), które potwierdza i podtrzymuje odrębność. Inaczej mówiąc, w teologii Tertuliana persona zawiera $\mathrm{w}$ sobie zdolność pełnego wyrażenia zarówno złożoności i wielości, jak i dynamicznej jedności ${ }^{45}$.

$* * *$

Tak więc, aby dostrzec choć trochę dynamikę i specyfikę teologicznej refleksji w oparciu o pojęcie osoby, trzeba nam nieprzerwanie sięgać do świadectwa Ojców naszej wiary. Pozostają oni dla nas wciąż niedoścignionym wzorem chrześcijańskiej oryginalności w podejściu do tajemnicy Boga objawionego w Jezusie Chrystusie. Nadając odmienności i jedności taką samą wartośćc $^{46}$, ukazują nam epifanijno-dialogiczną koncepcję osoby. Odwołując się do skrypturystycznego świadectwa, mocni wiarą w Jezusa Chrystusa, który jest szczytem i pełnią objawionego Boga w ludzkiej historii, pojmują osobe jako „byt” responsoryjny, obdarowany istnieniem i otwartym na innego w darze miłości. W świecie teologii patrystycznej osoby wszakże nie ma bez miłości. Osoba jest owocem odpowiedzi na wezwanie Odwiecznej Miłości. Nie należy jej zatem pojmować jako monady zamkniętej w sobie, szczęśliwej z powodu siebie, zwartej w sobie całości bytu. Osoba jest uobecnieniem międzyosobowej więzi - bez rozdzielania i bez pomieszania - poprzez wolny i bezgraniczny dar z siebie.

${ }^{44}$ Por. Wolinski, De l'économie à la ,théologie” (III siècle), s. $201=$ Wolinski, Sans cesse engendrés dans le Christ, s. 251.

${ }^{45}$ Por. Doumas, ,Persona” chez Tertullien, s. 43.

${ }^{46}$ Por. J. Ratzinger, Dogme et annonce, Paris 2012, 201-202. 
THE BEGINNING OF THE CONCEPT OF THE TERM PERSONA. A CONTRIBUTION TO A THEOLOGICAL THINKING ABOUT A PERSONAL BEING

\section{(Summary)}

The article presents the meaning of the term persona in the Latin literature. The author shows that Boetius' understanding of this term as individuum or rationalis naturae individua substantia is not sufficient. The author proposes to explore Tertullian's teaching about the human person. This ancient theologian used the term persona in a Christian sense. Thus he contributed to the development of the Christian vocabulary. We notice that in the Patristic sources there are keys for the theological reflection about the human person in a soteriological aspect; we can better understand the true nature of the human being (or person) in the light of the work of salvation accomplished by Jesus Christ.

Key words: person, individual being, nature, relationship.

Słowa kluczowe: osoba, indywidualne istnienie, natura, relacja.

\section{BIBLIOGRAFIA}

\section{Źródła}

Augustinus, De Trinitate, PL 42, 819-1098.

Cicero, De officiis, ed. T.E. Page - W.H.D. Rouse, LCL 30, London - New York 1913.

Cicero, De inventione, ed. T.E. Page - E. Caps - W.H.D. Rouse, LCL 386, Cambridge (Mass.) - London 1960.

Tertullianus, Adversus Praxean, ed. A. Kroymann - E. Evans, CCL 2, Turnhout 1954, 1157-1205; tłum. E. Buszewicz: Tertulian, Przeciw Prakseaszowi, ŹMT 4, Kraków $1997,35-86$.

\section{Opracowania}

Histoire du christiansime, t. 1: Le nouveau peuple (des origines à 250), éd. L. Pietri et allii, Paris 2000.

Housset E., La vocation de la personne. L'histoire du concept de personne de sa naissance augustinienne à sa redécouverte phénoménologique, Epiméthée, Paris 2007.

Jannot J.-R., Phersou Phersuna, Persona. A propos du masque étrusque, w: Spectacles sportifs dans le monde étrusco-italique. Actes de la table ronde de Rome (3-4 mai 1991), Collection de l'Ecole française de Rome 172, Rome 1983, 281-320.

La personne et le christianisme ancien, éd. B. Meunier, Patrimoines - christianisme, Paris 2006.

LÉTOUBLON F., La personne et ses masques: remarques sur le développement de la notion de personne et sur son étymologie dans l'histoire de la langue grecque, „Faits de langues" 3 (1994) 7-14. 
Moingt J., Théologie trinitaire de Tertullien, t. 2: Substantialité et individualité, Théologie 69, Paris 1966.

Nédoncelle M., Prosopon et persona dans l'Antiquité classique, RSR 82 (1948) 277-299.

Ratzinger J., Dogme et annonce, Paris 2012.

Skutsch F., Persona, w: Archiv für lateinische Lexikographie und Grammatik, t. 15, Leipzig, 1908, 145-146.

WojtyŁa K., Osoba i czyn, Kraków $1985^{2}$.

Wolinski J., Sans cesse engendrés dans le Christ. Treize études patristiques, Religie świata - świat religii 12, Lublin 2013. 